\title{
Matthew and apocalypticism as the "mother of Christian theology": Ernst Käsemann revisited
}

\author{
Andries van Aarde \\ Department of New Testament Studies \\ University of Pretoria ${ }^{1}$ \\ Apocalyptic(ism) was the mother of all Christian theology-- since we cannot \\ really class the preaching of Jesus as theology.
}

Käsemann [1960] 1969:102)

\begin{abstract}
The aim of this article is to reflect on Ernst Käsemann's dictum that apocalypticism was the mother of all Christian theology. Käsemann used the Jesus tradition behind the Gospel of Matthew for the substantiation of his argument and understood the process of marginalization in Matthew's community in light of the development between the charismatic Paul and the institutionalized Frïhkatholizismus. This article argues for a possibility other than the conflict between charismatic law-free Jesus' followers and apocalyptically oriented Jesus' followers. The setting of Matthew refers to post-70 $C E$ scribal activity and a conflict between the scribe Matthew, coming from a Jerusalem apocalyptically oriented Jesus group, and scribes who were in the process of establishing the first phase of a Pharisaic rabbinate on the border between Galilee and Syria.
\end{abstract}

\section{SUPPOSITIONS}

Using primarily Mark and Q as sources (Stanton 1992:66-71; Riches 1997:32), Matthew retold the Jesus story against the background of a particular process and mind-set. The process was that of the so-called "separation between the synagogue and the church" that

\footnotetext{
${ }^{1}$ Paper presented at the Gospel of Matthew Seminar, Studiorum Novum Testamenti Societas, $56^{\text {th }}$ General Meeting, Faculté de théologie de l' Université de Montréal, Canada, 31 July-4 August 2001.
} 
started after the destruction of the temple in Jerusalem in $70 \mathrm{CE}$. The mind-set was that of apocalyptic(ism) $)^{2}$ that Matthew took over from Mark and a later version of Q. All three of the synoptic documents present an understanding of the death and resurrection of Jesus in the light of an apocalyptic mind-set. The apocalyptic expectation was that this world would be transformed into the final Kingdom of God. ${ }^{3}$

According to a specific prophetic tradition (the so-called idea of the nations' pilgrimage to Mount Zion - e g Matthew 8:11f/Luke 13:28f,; Zech 2:11; Targum of Isa 2:2b; 2 Esdras 13:49; 2 Bar 72:3-6), the new age would dawn when the Messiah was revealed in Jerusalem as the Son of Man causing the nations come to Jerusalem to join the unified Israel. ${ }^{4}$ The Jesus movement in Jerusalem believed that Jesus "restored" Israel as an ethnic entity. Matthew conformed to the Jesus group in Jerusalem.

${ }^{2}$ In this article the expression "apocalyptic" is used as an adjective and "apocalypticism" as referring to the worldview of apocalyptic groups that sometimes produce a literary document called an "apocalypse" (see Murphy 1994:160-161). With regard to Käsemann's above-mentioned dictum, Murphy (1994:164) formulates as follows: "Since the work of Weiss and Schweitzer, scholars have wrestled with the degree to which apocalypticism influenced Jesus' thought. Käsemann claimed that although the early church was very apocalyptic, Jesus was not (1969). Presently, there is a strong movement stressing non-apocalyptic aspects of Jesus' teaching or of earliest Christian tradition, and seeing apocalyptic elements as later additions by the church .... On the other side are those who reason from such evidence as Jesus' association with John the Baptist, whose preaching is considered eschatological, and the apocalyptic nature of much of the early church, that it is likely that Jesus himself was influenced by apocalypticism" (my emphasis).

${ }^{3}$ The vicarious death of a martyr was an important dynamic in this expectation because the martyr died on behalf of others to procure a better future for them beyond death (see Theissen 1999:150). From this messianic outlook and with an apocalyptic mind-set, the Jerusalem faction apparently started a process of institutionalizing Jesus' last meal with close followers as a table fellowship symbolizing their participation in God's "spiritual kingdom." These followers of Jesus distinguished themselves from the circle of the disciples of John the Baptist. Like Jesus himself, some of them could initially have belonged to this circle. Their separation was symbolized by their distinctive understanding of the baptismal rite. The baptism by John the Baptist was a water ritual that initiated a lifestyle to be lived when and where God reigns. The Jesus group in Jerusalem institutionalized a "spiritual baptism" in the name of the Father, and the Son, and the Spirit of God as sign of initiation into a discipleship of the "heavenly kingdom" (see Mt 28:16-20). According to their "scribal" exegesis of the Hebrew Scriptures, God's "imperial rule" was inaugurated by Jesus. According to Matthew, Jesus was Israel's spirit-filled messiah who triumphed through his victory over death, something that the Son of Man would do (see Mt 27:51ff). The Son of Man is that triumphant apocalyptic figure who had been expected within an apocalyptic mind-set to come at that point in history when the experiences in this world would be almost unendurable, so that God's people began to fantasize about the inauguration of the Kingdom of God which would transcend the worrisome times that they experienced (see inter alia Dn 7:13-14).

${ }^{4}$ In Matthew (as in Mark), this cosmic event happened when, in accordance with Amos 8:9, the sun went down at noon (see Mk 15:33/Mt 27:45) and Jesus, in accordance with Daniel 7:13-14, was revealed as the messianic Son of Man igniting the "discipling" of all the nations (see Mt 28:18-20; Mk 15:39; Mt 27:54). In Mark (and Luke), the focus was moved from Jerusalem to the Gentiles. For Matthew, the journey into the Gentile world was not the issue. The focus was on the "lost sheep of the house of Israel" so that the temple in Jerusalem could become the house of prayer for all nations, including the impure and the outcasts (see Mt 21:12-16). For Matthew, the Son of David was the messianic Son of Man who was expected to inaugurate the utopia for the "lost sheep of Israel" (see inter alia Mt 15:24; 18:14; 20:28, 31; 21:15). 
For Paul and Mark, however, "apostles" were emissaries who should be distinguished from the Jerusalem faction. The agreement between Matthew 19:28 and Luke 22:30 supports this view. However, it is the difference between these two verses with regard to $\mathrm{Q}$ that is important. ${ }^{5}$ The discord demonstrates their respective attitudes towards the Jerusalem faction. These perspectives cohere with their overall ideological points of view. Matthew, who conformed to the Jerusalem tradition, wrote: "you shall sit on twelve thrones obtaining justice (кpívovтعs) (cf Horsley 1987:201-207) for the twelve tribes of Israel." ${ }^{6}$ Luke was ambivalent towards the Jerusalem tradition. On the one hand, Luke legitimized the "authority" of the apostles in Jerusalem but, on the other hand, probably on account of Pauline influence, did not regard them as "the twelve." Luke wrote: "You shall sit on thrones obtaining justice for the twelve tribes of Israel." For Paul, "the Israel of God" was totally transformed into a spiritual entity. He grounded his conviction in his understanding of Jesus' death and resurrection. ${ }^{7}$ The "mainstream" behind Paul's kerygma is also the apocalyptic mind-set. ${ }^{8}$ Apocalypticism can therefore be seen as the mother of the Jerusalem faction's theology, and as unthinkable without the belief in the resurrection from death.

\footnotetext{
${ }^{5}$ From a 70 CE post-war situation, this Q recension that Matthew and Luke used reflected on the position of the Jesus movement that originated in Jerusalem. It attested to a position of trying to clarify its selfidentity in light of the Pharisaic reformation at Jamnia and other synagogical centers on the border of Galilee and Syria (e g, Sepphoris, Tiberias, Capernaum, Bethsaida, and Korazin).

6 According to Horsley (1991:196) "those who have followed or persevered with Jesus are to be "establishing justice" for the twelve tribes of Israel in a function very similar to that assigned to the anointed one in Pss. Sol. 17:26-32 or to the twelve men and three priests constituting 'the Council of the Community' at Qumran in 1 QS 8:1-4."

7 The resurrection faith is, according to Paul, the sign of a new birth, a new start, a new creation (2 Cor 5:17; Gl 6:15), the birth of the "true Israel," the "Israel of God" (Gl 6:16).

8 According to C H Dodd ([1936] 1956:16), "Paul's preaching, "represents a special stream of Christian tradition that was derived from the mainstream at a point very near to its source. No doubt his own idiosyncrasy counted for much in his presentation of the Gospel, but anyone who should maintain that the primitive Christian Gospel was fundamentally different from that which we have found in Paul must bear the burden of the proof." Paul's "idiosyncrasy" is his emphasis on spirituality that transcends ethnicity.
} 
Ernst Käsemann ([1960] 1969), as far as I know, articulated this insight first. ${ }^{9}$ Käsemann also uses Matthew for the substantiation of his argument. This paper aims at assessing Käsemann's argument in light of present-day research on the social location of Matthew. It focuses on the intra muros/extra muros debate. This dissension yields to what Bornkamm (1961), in the early years of the redaktionsgeschichtliche studies of Matthew, referred to as the question of the setting of the Matthean community. Does the community already exist beyond the walls of (formative) Judaism, or has the clash between "synagogue" and "church" not yet reached finality? In a certain sense this question can be traced back to W D Davies. ${ }^{10}$ He himself read Matthew against the background of the consolidation of "orthodox Judaism" at the end of the first century CE (Davies 1966:315). ${ }^{11}$ This view was actually initiated in 1928 at the suggestion of Ernst von Dobschütz, and applied by Bacon ([1930] 1980) in Bacon's epoch-making study of the "five books" of Matthew against the "Jews."

Later scholars saw this problem as much more complex. According to Künzel (1978:163-164, 178, 258), for example, the community of Matthew experienced a Vierfrontenkrieg (four-fronted war): on one side the doppelte Frontstellung between the "extra-congregational", already accomplished breach between the synagogue and the

9 Käsemann's (1960:180) specific words are: "Die Apokalyptik ist - da man die Predigt Jesu nicht eigentlich als Theologie bezeichen kann - die Mutter aller christlichen Theologie gewesen." However, Käsemann's expression "all Christian theology" should be reduced to only the theology of the Jesus faction in Jerusalem. Other Jesus groups, contemporaneous to that in Jerusalem (e g, the communities respectively responsible for the formative stratum of $\mathrm{Q}$ and the first layer of the Gospel of Thomas), did not interpret the Jesus event from an apocalyptic perspective but from a sapiental one. According to Schmithals (1994:20; cf 1973:129; 1975:72), one can agree with Käsemann if the interrelationship between apocalypticism and Christianity is historically understood. Materially ("sachlich") seen, however, Christianity did not grow out from apocalypticism but "conquered" it.

10 "The engagement of Matthew with Judaism and the Old Israel needs no further comment. The one question which will not be silenced is whether this engagement took place intra muros, that is, as a dialogue, however crucial, within Judaism or extra muros, that is, an appeal or apologetic to the Synagogue from a church that was already outside it" (Davies 1966:290).

11 Related to this view, Hummel (1966) holds that while Matthew's congregation is engaged in a struggle with Judaism, and no longer participates in synagogue liturgy, it has not broken its ties with the synagogue. However, other scholars (cf inter alia Filson 1960; Blair 1967; Hare 1967) are of the opinion that the Gospel of Matthew should be read as a theological reflection against the background of the already accomplished breach between Judaism and Matthew's community. On the other hand, Bornkamm (see also Barth 1961; Held 1961), like Davies, assumed that the Gospel of Matthew should be interpreted against the background of the conflict which was still continuing intra muros. 
church; on the other side the "intra-congregational" doppelte Frontstellung between the nomistic scribes and the proponents of charismatic antinomism. Schweizer (1974), in turn, is of the opinion that Matthew intended to support those in the community who were confused as the result of a false alternative between a strict nomism in Pharisaic Christianity and a charismatic Hellenistic Christianity. ${ }^{12}$

\section{KÄSEMANN'S POSITION}

Käsemann (1969:82-107) says that the reaction of the first Jesus group to the death of Jesus leads us to the origin of "Christian theology". But a reconstruction of this "reaction" is difficult, as only fragments relating to the first Jesus group are available in Acts. Fortunately, historical criticism helps uncover information behind relevant texts. Gaps remain, however, because of all the small bits and pieces of the mosaic, and no clear delineation is possible of what exactly the earliest "theology" entailed. According to Käsemann (1969:82), it is a question of finding an adequate methodology. By means of these small bits and pieces, he attempts to find an answer to the question of the origin of "Christian theology". Käsemann (1969:83) makes use of the "method of reconstruction" in order to form a "overall view" from Matthew of the "theology" of the first Jesus group after the death of Jesus.

Matthew is used as a source as it contains information that does not occur in other gospels. The Matthew community can be located on the border between Palestine and Syria. He writes to "Gentile Christians" who knew the tradition of Israel well. By means of citations from the Hebrew Scriptures (e g, Mt 7:22-23; 23:8-10; 5:19), Käsemann indicates that behind these texts there is a history in which there clearly is tension, which emanated from "theological" differences. According to him, the opposing parties lay claim to the gifts of God's Spirit, while each judged the other with the "criteria of the Spirit”.

Matthew 7:22-23 (the conclusion of the Sermon on the Mount) is polemically aimed at "false prophets" (cf Carter 2000:191; Garland 1993:89). This polemic is aimed

12 The opinion of Barth (1961:54-154) is closely related to this view: the Gospel emphasizes the lasting authority of the Torah as opposed to the antinomism of the Gentile Christians in the congregation; simultaneously, the Gospel focuses on the universal implications of the Jesus events as opposed to the threatening "re-judaising" of the Pharisaic Christians in the congregation. 
not at the Pharisees, but at followers of Jesus with a "spirit-filled piety" who lay claim that only they have miracle working powers, such as the gifts of prophecy, exorcism and faith healing. ${ }^{13}$ The corresponding passages in Luke 6:46 and 13:26f do not contain these concrete examples. It would thus seem as if Matthew (as we also find it in Acts) refers to an enthusiastic group under the "Gentile Christians" in Palestine. Matthew distanced himself from this Jesus group. However, he does not mention or criticize his opponents' "errors". ${ }^{14}$ Käsemann concurs with Schlatter ([1933] 1963) that Matthew was probably an "ethical rigorist" and a representative of the earliest "Christian rabbinate". Matthew employs the judgement saying/formal curse of Psalm 6:9 against his opponent: "I did not

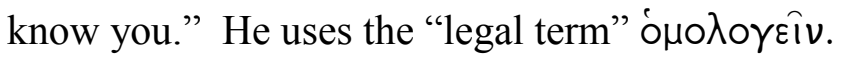

In Matthew 23:8-10 we find a polemic against the practice, in the context of a "Christian rabbinate", by followers of Jesus of also using the title "rabbi", and against the

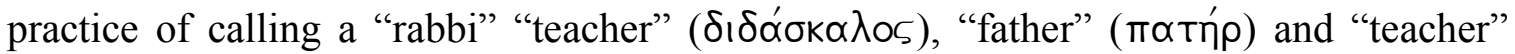

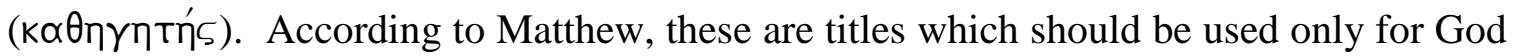
(or the Christ). Matthew's criticism takes place on the basis of Christ's "absolute rule" and the "eschatological freedom" of the followers of Jesus. It is a criticism which could only have emanated from the side of those "endowed with the spirit" and is aimed at people who, within the context of Israel, wanted to exercise authority in the community on the basis of the "authority of the Spirit of God" by means of their teaching of the Torah (Käsemann 1969:85).

Matthew 5:17-20 is a specific example of a polemic with regard to the conservation of the Torah. Matthew prescribes the conservation of the Torah up to the last iota and title. It is clear that Matthew here makes use of material from the tradition that he interprets in a different way than would have been the original intention. According to Käsemann, Matthew was part of a Jesus group which already conducted missionary work under the Gentiles and that was no longer bound to the cultic law. Käsemann (1969:85) understands Jesus' radical demand for obedience to the Torah therefore not literally.

13 Mt 7:21-23, according to Hare (1993:86), reflects a distinction between "eminent Christians" (="outstanding church leaders") and "humble Christians."

${ }^{14}$ Carter (2000:141) has a similar view with regard to Mt 5:20. 
According to Matthew 5:20, Jesus' demand relates to a "better justice" than the justice demanded by the prescriptions of the "scribes and Pharisees".

The form of Matthew 5:19 is important as it can be typified as a "sentence of holy law". It is a prophetic proclamation ${ }^{15}$ with a protasis and apodosis, which expresses the relation between guilt and punishment or duty and reward. The protasis often serves as the introduction of a casuistic law and the apodosis as an apodictic, infallible divine law. In the "rabbinate" the lack of a distinction between "secular" and "religious" legislation led to the disappearance too of the distinction between the casuistic and the apodictic law. In both forms the reward amounted to sharing in the kingdom of the heavens when God will judge the world. The judgement might be announced by prophets, but it is God who will carry out the judgement at the end of time. People therefore take note of the announcement of punishment, which will ensue if false teaching is followed, but they no longer apply it to themselves. Mt 5:19 is an example of such an "eschatological jus talionis" (cf also Käsemann 1954-55:124-147).

According to Käsemann (1969:86), Matthew here maintains a tradition which arose in the contexts of a "legalistic Jewish Christianity". But, alongside the same eschatological seriousness of the usual jus talionis, the prophetic proclamation in Matthew receives another meaning as the requirement to observe the Torah is partially or completely suspended. "We are therefore watching the progress of what can only be called a confessional controversy in primitive Christianity" (Käsemann 1969:86).

\footnotetext{
15 Matthew, according to Garland (1993:62), presented Jesus as the prophet like Moses whom Dt 18:15-20 expected.
} 
Aside from the Jesus group represented by Matthew, there was also another Jesus group. In the past some have thought that Matthew aims his attack at Paul. According to Käsemann, this, however, does not seem entirely to have been the case, although Paul's influence might be part of what Matthew aimed his gospel against. ${ }^{16}$ But it would be more correct to accept that Matthew aimed his gospel against a Hellenistic group that consisted of Stephen and his followers. ${ }^{17}$ They founded a spirit-filled enthusiastic group to which the mission to non-Israelites was more important than obedience to the cultic law. The temple in Jerusalem was no longer the centre of their life or the symbol of God's presence.

According to Käsemann (1969:87), for the first time in the history of the church a situation arose in which spirit is being set against spirit. Mt 10:5f is another example where we hear Matthew's opinion on this matter. This verse does not occur in the other Synoptic Gospels. Here we find the strictest form of "Jewish Christendom" that was not in favour of any mission outside the borders of Israel (even though mission to Gentiles were already underway). ${ }^{18}$ Matthew's aversion to the mission to Gentiles and Samaritans should, according to Käsemann, be understood from an apocalyptic perspective that was already reported in the Old Testament. ${ }^{19}$ According to this idea of the nations'

16 Bultmann (1965:138) reckons, in his History of the Synoptic Tradition, that Mt 5:17-19 "derives from the discussions between the more conservative (Palestinian) communities and those that were free from the law (Hellenistic)." In his Theology of the New Testament, Bultmann (1952:54) describes this "attitude toward Hellenistic Christianity, especially toward Paul" as follows: "Presumably a retrogression had taken place so that the old scruples and fidelity to the Law had gradually gained ground; such was completely the case later with Jewish-Christian sects. This is partly attributable to the personal influence of James, the Lord's brother, and is partly a reaction against criticism of the Law and the temple-cult on the part of the Hellenistic Church." In present-day Matthean research, David Sim (1998:207-209), particularly, revives Matthew's alleged anti-Pauline tendency with regard to Mt 5:17-19. "Scholars have long noted that these sayings reflect the theological position of Christian Judaism, and were seemingly created by Christian Jews in the course of their debates with the proponents of the law-free gospel. It is likely that each of these statements was composed well before the composition of the Gospel, perhaps even at the time of Paul and James, for the specific purpose of countering fundamental Pauline claims about the relationship between the Christ and the law ... This crucial section of the Sermon on the Mount therefore attacks the two major parties opposed by the Matthean community. The Pauline churches are criticised for rejecting the law, while the scribes and Pharisees are attacked for their misinterpretation of it" (Sim 1998:207, 209).

17 More or less, with variations, G Barth (1963:71) and Davies \& Allison (1988:497), among others, advocate this view.

18 Acts reports the same matter.

19 See, e.g., Zech 2:11; cf also Targum of Isa 2:2b; 2 Esdras 13:49; 2 Bar 72:3-6. 
pilgrimage to Mount Zion, God will gather Israel and the nations on Mount Zion where they will praise him. God will gather the "lost sheep" and care for the Gentiles. People should not assume this honour at God's expense by themselves carrying out the mission to the Gentiles. The only thing that Matthew expects from the followers of Jesus is that they bring together the "lost sheep of Israel" in order for the Parousia of God to arrive. ${ }^{20}$ "It follows that all that can be done in the earthly present is to lead the lost sheep of the house of Israel back into the unity of the messianic people of the twelve tribes for the precise purpose of enabling the Parousia to come to Pass" (Käsemann 1969:88). But the opinion of the other group was that the end of the world had arrived with the Easter events and the pouring out of the Holy Spirit. Mission to the Gentiles is an eschatological sign begun by God and not by human beings.

The two groups therefore thought differently with respect to the "end of time." The one group persisted in Israel's national hope, while the other group went beyond this eschatological tradition - though both lay claims to being filled with the spirit. "Being filled with the spirit" resulted in the one group limiting mission work to the borders of Israel (as we find it in Mt 10:5), while this exact same "being filled with the spirit" compelled the other group to engage in the mission to the Gentiles (as we find it in Acts 13:2). Both groups were of the view that the Parousia would take place soon (as we find it in Mk 9:1 and Mt 16:28; 24:34). They believed it would occur even in their time. They celebrated communion in the expectation of the imminent heavenly feast. It was not being filled with the spirit as such that was the reason for the dispute between the two groups, but different "theologies" adhered to by the groups. Against this background, Käsemann (1969:89) reconstructs his understanding of the "origin of Christian theology."

The "Hellenists" (see Acts 6 - cf Riches 1997:46-47) were driven from Jerusalem and, in Antioch, they became the precursors of the later "Pauline apostolate". The "strictly Judaic-Christian group" gathered in Jerusalem. The members of this Jesus group found themselves more and more in an ever-growing "Gentile Christianity". In the end,

${ }^{20}$ According to Käsemann (1969:88), this is more or less Paul's message in Rm 11:25f. 
they were marginalized as a sect. ${ }^{21}$ In the midst of the ever-growing mission to Gentiles, they focused their missionary work on the "lost sheep of Israel." Their exchange of "being filled with the spirit" for "legalism" led to their replacing Peter with James (the brother of Jesus). ${ }^{22}$ Käsemann (1969:89-90) says he does not know what happened to the Jesus group within the context of the Judean national tradition that did not immediately subject itself to the new leadership in Jerusalem.

According to him, this question does, however, need to be asked on the basis of Mt 10:41. ${ }^{23}$ Here we find a tradition that is not unique to Matthew. In $\mathrm{Q}$ it is used to indicate the authority of the disciples in their mission task. According to rabbinic principles, the disciples were the proxies of the one who has sent them. The disciples of Jesus therefore fulfilled the function and role of "apostles" and, as "prophets", announced God's future. It is clear that Matthew took over this tradition, but then in altered form. ${ }^{24}$ The strange form of the jus talionis pronouncement in Mt 10:41 is striking as a result of the "absolutely exact correspondence" between the protasis and apodosis. The apodosis refers to an "eschatological future" which does not express punishment but reward. The message of the proclamation of this adapted "eschatological reckoning" is that the "eschatological future" has already arrived in Jesus and that Jesus is represented in the actions of the disciples/apostles/prophets. Jesus as "universal judge" observes when where people do not act as his representatives.

\footnotetext{
21 For the recent discussion on "Matthew's sectarianism," see Luz (1989:219); Overman (1990:154); Saldarini (1991:44-60; 1994:84-123); Duling (1995a:159-182; 1995b:1-30); Sim (1996:182-192; 1998: 113); Riches (1997:76-78); Carter (2000:43-49).

${ }^{22}$ It is clear, however, that those "filled with the spirit" in Jerusalem did not immediately disappear from the scene after the martyr's death of Stephen and James, the son of Zebedee, nor with either the departure of Peter from Jerusalem or with the start of the Jewish wars. If that were the case, then we would be hardpressed to explain the clear tracks of this Jesus group in the Gospels and Acts (and even in the Gospel of John) (see Käsemann 1969:89-90).

23 "The one who accepts a prophet as a prophet will be treated like a prophet; and the one who accepts a virtuous person as a virtuous person will be treated like a virtuous person" (Mt 10:41 - The Complete Gospels, ed. by R J Miller 1994:76).

${ }^{24}$ For a critical discussion in present-day Matthean studies, see Luz's (1989:65-66) view on Matthew's "closeness to the Q tradition" with respect to his "treatment of the offices of prophet and scribe" (see Riches' [1997:53-55] description of this view).
} 
For Käsemann (1969:90-91), the distinction between "prophet" and "virtuous" person in Mt 10:41 is therefore important. According to the theory of E Meyer, ${ }^{25}$ it would appear as if there were class differences in the community. "Prophets" were apparently responsible for the leadership within the community, while the "virtuous" were those who wanted to conserve the Torah. ${ }^{26}$ Such a distinction can also be inferred from the beatitude of Mt 13:16f. ${ }^{27}$ The entire community forms part of the descendants of the Old Testament prophets and shares, according to Mt 5:12, ${ }^{28}$ the martyr's lot of the

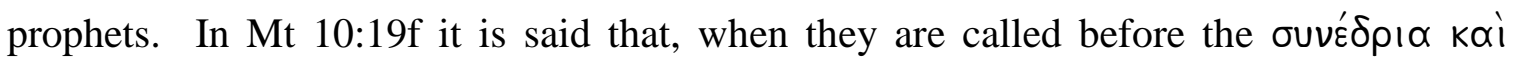
ouvarwrais (Mt 10:17), the "Spirit of the Father" will help them with the gift of prophecy. ${ }^{29}$ This is one of the few remainders in Matthew where traces of a "general endowment of the Spirit" are found. When he refers to it, he does so in the context of suffering which will still occur.

If we were to inquire into the social location of the early Jesus groups, where such a distinction between "prophets" and the "virtuous" is found, then Jerusalem must be left out of the equation. Here "the twelve (apostles)" exercised leadership. According to Käsemann (1969:92), the only acceptable possibility would be the small communities of Jesus groups on the border between Palestine and Syria. As a result of their size one could expect the leader to be a charismatic person. In view of Mt 10:41 these "prophets" were dependent on the hospitality of others. The distinctive identity of these communities was determined by their view that they were in possession of the Holy Spirit. Being filled with the spirit resulted not only in their holding on to the promise of

${ }^{25}$ Quoted by E Klostermann (1938:93).

26 In Lk 10:24 the opposition is that between "prophets" and "kings" - the meaning therefore differs completely from that in Matthew.

27 "How privileged are your eyes because they see, and your ears because they hear. I swear to you, many prophets and righteous ones have longed to see what you see and didn't see it, and to hear what you hear and didn't hear it" (Mt 13:16-17 - Complete Gospels)

28 "Rejoice and be glad! In heaven you will be more than compensated. Remember, this is how they persecuted the prophets who preceded you" (Mt 5:12 - Complete Gospels).

29 "The prophets only bring into the clear light of day the determining force of the whole community - the Spirit of prophecy himself who governs this community and therefore guides it by means of the instruments he considers appropriate" (Käsemann 1969:91). 
the imminent Parousia, but also the authority of their calling as missionaries. In this regard, being filled with the spirit and apocalyptic theology are linked to one another.

Käsemann (1969:92) substantiates this conclusion with his analysis of the prophetic proclamation that has the form of the eschatological jus talionis. This legal form belongs to the category that Bultmann (1965:138ff) called "church rules". The distinctiveness of the "eschatological jus talionis" is that it combines an apocalyptic perspective with being filled with the spirit (which originates with a prophetic inspiration). Matthew uses this form often, while it seldom occurs in the other gospels. In the context of the formative "rabbinate", Matthew links Jesus' message to this kind of divine law without having been a legalist. Matthew 19:28f. as well as Mt 10:41 and 42 are examples of this (see Käsemann 1969:93). Matthew, however, is not the original creator of these laws. It would appear as if the earliest Jesus community preserved them independently of Matthew. This is, however, not the only indication of the prophetic message of being filled with the spirit after the death of Jesus.

The question now is whether the historical Jesus used this form of prophetic pronouncements. According to Käsemann (1969:101), we can only determine this if we can determine the central message of Jesus. Albert Schweitzer's view that Jesus himself was an apocalyptic ended, according to Käsemann (1969:101), in a cul-de-sac.

The situation was this: Jesus admittedly made the apocalyptically determined message of John his point of departure; his own preaching, however, did not bear a fundamentally apocalyptic stamp but proclaimed the immediacy of the God who was near at hand. I am convinced that no one who took this step can have been prepared to wait for the coming Son of Man, the restoration of the Twelve Tribes in the Messianic kingdom and the dawning of the Parousia (which was tied up with this) in order to experience the near presence of God. To combine the two would be, for me, to cease to make any kind of sense.

(Käsemann 1969:101-102)

We must, rather, be able to see that the earliest Jesus group, after the death of Jesus, reacted to the preaching of Jesus about God by replacing it with a "new apocalypticism" 
which followed the resurrection faith and the reception of the Holy Spirit. Apocalypticism is therefore the "mother of all Christian theology because we cannot classify Jesus' preaching as theology." According to Käsemann (1969:102), there were two characteristics of the apocalypticism that gave rise to the first "Christian theology". The one is the "sentence of holy law" of which Matthew 12:32 is an example: "He who speaks a word against the Son of Man will be forgiven. But he who speaks a word against the Holy Spirit will not be forgiven, either in this age or in that which is coming."

On the basis of this passage we realize that the "primitive Christian mission" must have experienced opposition, exactly because they were seen as people who were controlled by the Spirit of God. This opposition they experienced as if directly aimed at the Holy Spirit. Such an attitude emanates from evil. ${ }^{30}$ In prophecy divine epiphany on earth comes to perfection with an eschatological magnificence that surpasses that of the historical Jesus. Jesus' life, as judged in the light of resurrection faith, "remained still in the shadow of a hiddenness which rendered misunderstanding, doubt and unbelief understandable and forgivable" (Käsemann 1969:103). But to resist oneself against the unveiled appearance of God, as it finds expression in the prophetic spirit, is the one unforgivable sin. The same problem that lies at the basis of the entire New Testament theology, namely the relation between the preaching about Jesus and the message of Jesus is here, too, present. And the answer here, too, is that the historical Jesus and his ipsissima verba cannot be identified clearly. But what is clear is that Jesus himself did not make use of the form of the "eschatological jus talionis", but also that Matthew knew it as a form that was already being used by followers of Jesus in the apocalyptic tradition of the Old Testament. ${ }^{31}$

\footnotetext{
30 The other reaction is perhaps something like that of Paul in 1 Cor 14:24f.: "But if all prophecy, and an unbeliever or outsider enters, he is convicted by all, he is called to account by all, the secrets of his heart are disclosed; and so, falling on his face, he will worship God and declare that God is really among you."

31 The other characteristic of the apocalyptic, which gave rise to the first "Christian theology", Käsemann (1969:103) finds in Mt 10:13f. The same "complex" as that in Mt 12:32 also occurs here. In the missionary the epiphany of salvation appears. The missionary is as it were personally the carrier and embodiment of this salvation in his capacity as "emissary of the Lord." It is the miracle making power of

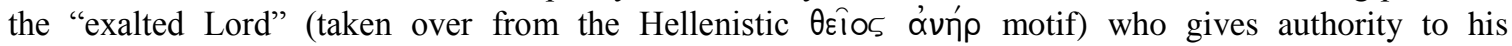
messengers and also calls them personally to account. According to Käsemann (1969:103-104), the history of "primitive Christianity", from the beginning up to the frühkatholishe period, consisted of one big struggle to bring the relationship between the Spirit, the Gospel and Christology to expression.
} 
The heart of "Christian" apocalypticism, according to the Book of Revelation and the Synoptic Gospels, is God who sits on the heavenly throne, with Christ as the eschatological Son of Man at God's right hand. ${ }^{32}$ It is a proclamation that God is just. God's judgement is no longer only expected, but is something that is given and will be disclosed at the Parousia. It is already a given to all who are waiting in obedience for the final moment of the Parousia, to those who hear and accept the prophetic pronouncements of the last judgement. In Mt 10, everyone is called to confess Christ as the future Son of Man, to follow the Christ even unto death. This prophetic proclamation explains the Old Testament eschatologically. The community of Matthew accepted that a huge amount of adversity and suffering still lay ahead for them. It is here where the big difference is to be found between those filled with the spirit in Matthew's community and those filled with the spirit in, for instance, Corinth, who believed that they had already overcome the worst punishment. For the latter group, the end of history had already taken place. In the light of Mt 10:22 $2^{33}$ and $24: 13,{ }^{34}$ the "eschatological law" points out that the acceptance of misery and suffering was the proof of future salvation by God. Misery and suffering point to the path of redemption. Mt 10:23 ${ }^{35}$ is closely connected to this idea.

This hope, unfortunately, collapsed and, with it, the entire structure of apocalyptic theology in the time after the death of Jesus. On the basis of the resurrection faith, the community of Matthew awaited the renewal of the "twelve tribes" of Israel, while they

\footnotetext{
${ }^{32}$ Cf. Hengel $(1995: 183,188)$ : "In early Christianity analogous ideas are supposed in Matt. 19:28 = Luke 22:30; 1 Cor. 6:2f and Rev. 20:4ff. More significant was the parallel tradition that the son of man / messiah as representative and saviour of the true people of God is given the authority to judge; this documented in the Similitudes of 1 Enoch and in particular in the teaching of Jesus and in earliest Christianity including Matt. 25:31ff. ... [A]pparently dependent upon the language of the Similitudes - there [Matt. 19:28; 25:31] is twice mentioned that the Son of Man 'sits on the throne of his glory' and the twelve disciples as the followers of Jesus become his college of associate judges..." According to Hengel (1995:173), "in particular the motif of sessio ad dexteram was material common to early Christian congregations, whether in Corinth, Antioch or Rome, and in my opinion demonstrates incontestably that they go back to the Jerusalem congregation.” (Cf. also Hengel 1995:155, 158, 167, 181.)

33 "And you will be universally hated because of me. But those who hold out to the end will be saved" (Mt 10:22 - Complete Gospels).

34 “And as lawlessness spreads, mutual love will grow cool” (Mt 24:13 - Complete Gospels).

35 "When they persecute you in this town, flee to another. I swear to you, you certainly won't have exhausted the towns of Israel before the [Son of Man] comes" (Mt 10:23-Complete Gospels).
} 
strove for the conservation of the Torah and fought against the mission to Gentiles. ${ }^{36}$ The Easter event led to the origination of theology, first that of the small Jesus group from within the tradition of Israel which later developed into a sect inside the "big church", until it eventually disappeared with only very few traces that remained. This becomes clear in Matthew $16: 19,{ }^{37}$ which is characteristic of the prophetic proclamation of the eschatological jus talionis.

A story of confusion and misunderstanding is connected with this saying ominously enough from the very beginning, in that a Petrine party was already confining to their leader in his role of first witness of the Resurrection the plenary authority promised to the whole community corporately in Matt. $18.18^{38}$; in so doing, they were declaring themselves to be a sect. They thought to be able to defy the gates of hell in the name of their master; but they were unable to resist the sands of time which buried them. Dare we say that in this very episode primitive Christian apocalyptic[ism] may be see as the archetype of what is always happening in the history of the Church? Or has there ever been a theological system which has not collapsed?

(Käsemann 1969:107)

\section{ASSESSMENT}

My assessment of Käsemann's view consists of arguing for an agreement with his thesis that Matthew conformed with the earliest Jesus group in Jerusalem, although I differ with him with respect to the underlying position of the thesis, that is that Matthew reflects neither an "anti-Paulinistic Antiochean" writing nor an "intra-Christian" controversy. My

\footnotetext{
36 According to Meier (1997:639 note 12), "(t)he viewpoint of the late-first-century church [depicting a Galilean/Syrian situation] may be reflected ever so fleetingly here," that is Matthew's employment of the role of "the twelve."

37 "I shall give you the keys of Heaven's domain, and whatever you bind on earth will be considered bound in heaven, and whatever you release on earth will be considered released in heaven" (Mt 16:19 - Complete Gospels). This saying should be seen as reference to the "teaching authority of the rabbinate" (see Jeremias [1938] 1985:440; Overman 1990:104-105; Riches 1997:75).

38 "I swear to you, whatever you bind on earth will be considered bound in heaven, and whatever you release on earth will be considered released in heaven" (Mt 18:18 - Complete Gospels).
} 
position is rather that Matthew mirrors a post-70 CE conflict in South-Syria/North-Galilee between village scribes among Jesus groups and synagogical scribes among the Pharisees.

However, the polemic between Jesus' teaching and the Pharisees in the gospel tradition $^{39}$ (such as the Sayings Gospel Q and the Gospel of Matthew that used Q as source) should therefore not be seen anachronistically as two established institutes, a "church" and a "synagogue", in conflict with each other. The conflicting interests were rather the result of a process of institutionalization that took two directions in the village communities. $^{40}$ The context of this early scribal activity among Jesus' followers and Pharisees was that of the bet-midrash (formative Judaism) rather than that of the bene haknessett (normative Judaism). From the second century onwards the synagogue began functioning separately from the village administration (see Cohen 1992:157-173; Levine 1992:201-222). During the period of formative Judaism the scribe who was responsible for the Gospel of Matthew seems to be in conflict with some scribes of the Galilean/Syrian village administration who were in allegiance to the elite ex-Jerusalem

39 According to Kloppenborg (2000:200) it is "self-evident that insofar as Q represents a written document, it is the product of scribal technology." Kloppenborg (2000:201) describes the consequences of this as follows: "[W] ho besides scribes had the ability to compose it this way and who would have chosen a typically scribal genre? ... Q does in fact betray a number of features characteristic of scribes ... : interest in the process of as well as the context of instruction ... [S]cribes did not uniformly serve the interests of the ruling élite. There is ample evidence from Egypt to indicate the presence of a variety of scribes, of varying educational levels, in towns and villages, some serving in the apparatus of the provincial administration and others functioning as free-lance professionals. The $\kappa \omega \mu о \gamma \rho \alpha \mu \mu \alpha \tau \varepsilon i \varsigma$ (village scribes) were concerned with tax and census matters. But the writing of loan and lease agreements presupposed the existence of private professionals prepared to assist in these transactions. ...There is no reason at all to suppose that this sector was uniformly aligned with the ruling classes against the poor or that this sector functioned exclusively as retainers of the élite. $\mathrm{Q}^{1}$ reflects the technology and interests of these private professionals." Kloppenborg (2000:203-204) argues that $\mathrm{Q}^{2}$ displays a "contrasting ethos" with "competitors" and suggests, "that at this stage of Q, the rhetorical situation demanded a defense or legitimation of the Q people's existence.” Kloppenborg (2000:204) describes the Sitz im Leben of $\mathrm{Q}^{2}$ as follows: “... the Q people are associated with towns sufficiently large to have markets and a small scribal sector, and sufficiently proximate to the larger centers of Tiberias and Sepphoris to come into periodic contact with Pharisees and other representatives of the Judaean hierocracy. Q's cultural allegiances, however, are with the Galilean countryside and against the city, which is regarded with distrust and suspicion. In defense of the Jesus movement, the framers of Q construct a notion of Israel and its epic heroes which stands in opposition to Jerusalem, the Herodian dynasty, the Pharisees and lawyers, and the unbelief that is encountered in the market places."

40 The gospel reports of Jesus teaching in the synagogues in Galilee mention that he was challenged by Pharisaic scribes (see Mk 1:21, 27; 2:1,6). "It seems likely that the tradition of Jesus' teaching behind such literature as Mark, Q, and the Didache would have been cultivated in Galilean communities" (Horsley 1996:184). 
scribes (cf Orton 1989:49). ${ }^{41}$ As a grammateus that became a "disciple" of the "kingdom of heaven" (Mt 13:52), ${ }^{42}$ the author of the "First Gospel" could have had his roots in Jerusalem. I substantiate this assumption by a discussion of what Bultmann (1965:130150) refers to as "legal sayings" (Gesetzesworte) or "church rules" (Gemeinderegeln) and Käsemann (1969:86) as "sentence of holy law," the "eschatological jus talionis".

For the purpose of this paper, I focus on a Son of Man saying that belongs to the group of "prophetic and apocalyptic sayings" (Collins 1996:151). My intention is to assess Käsemann's view by means of my understanding of Matthew 12:32. ${ }^{43}$ The similar logion in Mark (see Mk 3:28-29) does not contain the title Son of Man. Mk 3:28-29 reads: "All sins and blasphemies will be forgiven the sons of men (Tốs viois twv $\left.\alpha_{\alpha} v \rho \omega \dot{\pi} \omega \nu\right)$ as many as they commit; but whoever blasphemes against the Holy Spirit will not have forgiveness forever" (RSV). According to Collins (1996:148) the similar variant in Didache $11: 7 b^{44}$ is an indication "that the Markan form is not idiosyncratic". This earlier tradition behind Mark (and Didache) also places the following on the lips of Jesus: "if a human sins against another human, forgiveness is available ..." (Collins 1996:148; my italics).

If this logion can be traced back to the formative stratum of the $\mathrm{Q}$ tradition (independently attested to by Mark), it represents the subversive teaching that the act of

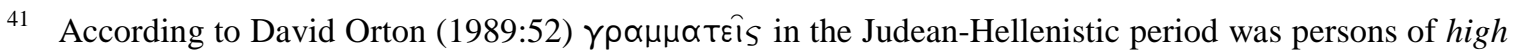
official rank and authority: "They were overseers, instructors and judges; they bear Mosaic authority and are connected with Levites and the implementation of the Law." Neusner (1991:161) refers to the Judean scribe of this period as follows: "The union of the scribe and the priest yielded the sage who bore the honorific title Rabbi."

42 Despite Donald Senior's (2001:18 note 27) seemingly concurring with my comments on Matthew's combination of "old" and "new" (see Mt 13:52) with respect to Matthew's understanding of Jesus' conservation of the Torah (see Van Aarde 1994:127-141), I am not in agreement with Senior's view on Matthew's place in early Christianity. According to Senior (2001:18), Matthew's "ultimate goal was the realization of an ecumenical vision uniting Jewish and Gentile Christians in one community."

43 "And the one who speaks a word against the [Son of Man] will be forgiven; but the one who speaks a word the holy spirit won't be forgiven, either in this age or in the one to come" (Mt 12:32 - Complete Gospels).

44 "Do not test or examine any prophet who is speaking in a spirit, 'for every sin shall be forgiven but this sin shall not be forgiven" (Did 11:7b - Sayings Parallels 139, ed. by J D Crossan 1986:68). GThom 44 reads: "Jesus said: 'Whoever blasphemes against the Father will be forgiven, and whoever blasphemes against the Son will be forgiven, but whoever blasphemes against the Holy Spirit will not be forgiven either on earth or in heaven" (Sayings Parallels 139). 
forgiveness is a general human matter and not limited to priests. In the context of $Q$ it can be expected that this type of teaching would be subjected to the interpretation of the Scriptures since Q (and Mark and Matthew) probably originated in the context of scribal activity and the controversy between scribes among Jesus' followers and Pharisaic scribes (see Kloppenborg 2000:201; Arnal 2001:168-172). Collins (1996:148) is of the opinion that 1 Sam 2:25 could have played a role in this regard: "If a man sins against another man [אישי לאישי], God may mediate for him; but if a man sins against the LORD, who will intercede for him?" (NIV).

If Mark 3:28-29 reflects an earlier tradition, the expression "sons of men" was used in the indefinite generic form and not as a titular reference to Jesus. Q (= Lk 12:10) which has a synagogical controversy as Sitz im Leben, draws the logion into a context of whether or not Jesus' teaching could be acknowledged. In this context Jesus is honoured with the title Son of Man. ${ }^{45}$

Collins (1996:148) asks why such a "shift" from the generic use of the expression "son of man" to Jesus as the Son of Man would have taken place: "It is possible that Jesus spoke such a saying, using the generic or indefinite Semitic idiom [see Vermes 1967:311319], and that it gave rise to the variants. But this reconstruction leaves unanswered the question why someone who handed on the saying made a shift from speaking about humans or men in general to speaking of Jesus as the human or the Son of Man."

A possible explanation of the use of the title Son of Man in Q could be that a subversive saying of Jesus developed into the titular attribution of honouring

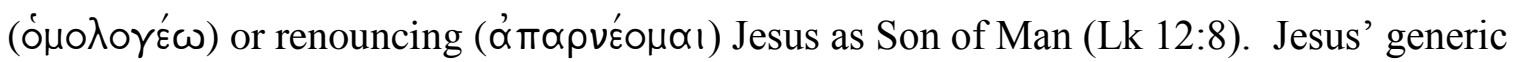
use of sins against people in general that can be forgiven by God (according to 1 Sam 2:25) is, in the context of scribal activity, applied in such a way that Son of Man (as God's "mediator") could forgive sins committed against him (Jesus as the Son of Man),

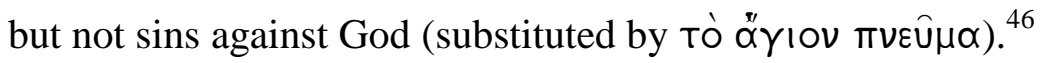

${ }^{45}$ Casey (1976:147-154; cf 1979:229; Bauckham [1985] 1995:245-255) concludes that the "original" form of the logion in Aramaic had "two levels of meaning" (see Collins 1996:148 note 35). According to him the saying refers to sins against people in general in the first place, and in the second place to sins against Jesus as the Son of Man. Casey supposes that the Greek translators were unaware of this ambivalence in the Aramaic and interpreted it solely as a reference to Jesus as the Son of Man.

${ }^{46}$ See David Flusser, in Luz ([1989] 2001:208 note 109). 
Placing Mt 12:32 within the context of an intra muros "scribal debate" makes, in my view, more sense than Käsemann's view that we are here dealing with "GentileChristian" resistance against an enthusiastic Jesus group who appealed to a "divine epiphany" in their lives.

\section{FINDINGS}

Käsemann anticipated present-day Matthean scholarship. He demonstrated that studies of Matthew's community as a marginalized group should not be carried out independently of the question of the interpretation of the Torah. The question as to the interpretation of the Torah, again, should not be investigated independently of the apocalyptic tendency in Matthew. The difference between the role of the disciples in Matthew and Mark (and Luke) is related to this problem. ${ }^{47}$ The opposition between Matthew and the post-70 CE scribes and Pharisees is transparent in the narrative on the opposition between the disciples and the scribes and Pharisees. ${ }^{48}$

Käsemann's insight in understanding the process of the marginalizing of Matthew's community in terms of the development between the charismatic Paul and the institutionalized Frühkatholizismus is interesting and can be supported by means of the recent investigations into the alleged anti-Pauline tendencies in Matthew. However, I

\footnotetext{
47 Mk 3:7 make a clear distinction between Jesus' disciples and the crowds. Mk 3:13 could therefore be interpreted that Jesus summoned "the twelve" out of a larger group of disciples. This is how Luke understood Mk 3:13: "And [Jesus] called his disciples, and chose from them twelve...." With regard to Jesus' calling of the "rich man" to be a disciple (Mk 10:17-22) one can also argue that a larger group of disciples apart from "the twelve" existed. The fact that the "rich man" reportedly responded negatively seems to be irrelevant for Mark when he referred to the "rich man" as a potential disciple. However, in a number of cases Matthew redactionally changed Mark's tendency to equate "the twelve" with all of the disciples. In the case of Levi, Matthew transformed "the toll collector's" name into "Matthew" - a name that is found in the list of "the twelve." Actually, in the Gospel of Matthew, no individual "disciple" appeared who was not named in the list. Whereas Luke (6:12-16) took over the Markan report of the selection and the naming of "the twelve" (Mk 3:13-19), Matthew did not narrate a story in which Jesus called "the twelve" out of a larger group of disciples. When Matthew referred to the calling of the "rich man" and his negative response, he characterized him as someone who associated himself with Jesus' opponents (see Van Aarde 1994:56-57; 1999:795-826).

48 The development of the rabbinical movement in the $2^{\text {nd }}$ and $3^{\text {rd }}$ centuries took place in centres such as Sepphoris, Tiberias, Capernaum and Chorazin (see Schams 1998:299). However, traces of such scribal activity during the period of formative Judaism can be found in textual references in these same places (see Hare 1967:103-114; Neusner 1991:157-163). "Texts" such as the Jesus tradition (i.e., those that originated in the pre-70 CE Jesus community in Jerusalem, independent of the temple), that were transmitted orally and found their way into texts like the Gospel of Matthew, can be attributed to such scribal activity (see Schams 1998:180-198; cf Dreyer 2001a; 2001b:315-327).
} 
have in my interpretation of Matthew 12:22-37 pointed to a possibility other than the conflict between charismatic law-free Jesus' followers and apocalyptically oriented Jesus' followers.

My suggestion will be that the situation in Matthew does not point to a "double" opposition, that between Jesus' followers from opposing Israelite and Hellenistic (Pauline) circles, and that between Jesus' followers and scribes from the circle of formative Judaism. Matthew and Paul present "two examples of how the early Christian community perceived Jesus to provide a new basis for ethical living" (Morhlang 1984:131). "To try to harmonize the two would be as misleading as to try to play one off against the other" (Meier 1976:169; cf Mohrlang 1984: 191 note 1). Perhaps we are, rather, dealing in the setting of Matthew with one single conflict: in the context of the post-70 CE scribal activity, between the grammateus Matthew, coming from a Jerusalem apocalyptically oriented Jesus group, and village scribes who were in the process of establishing the first phase of a Pharisaic rabbinate on the border between Galilee and Syria. $^{49}$

Käsemann was quite correct when he said that Matthew's community became a progressively smaller group. He was also correct when he said that the historical Jesus did not see himself as the apocalyptic Son of Man. Mark, $Q^{2}$, Luke and Matthew inherited this tradition from the first Jesus group in Jerusalem. However, Käsemann was on the wrong track when he claimed that Matthew's community disappeared within the context of the frühkatholische Christian community - although the "First Gospel" as such became known within this context and was widely accepted by the "catholic church". Matthew's community, however, seems to have had a different history. Marginalization happened within the context of formative Judaism. Within this context, Matthew's group (and, likewise, "Ebionite" Jesus groups in Trans-Jordan) disappeared. As an apocalyptic messianic movement, already a marginalized minority within the context of the formative

\footnotetext{
49 The Jesus movement in Galilee and the work of early post-70 CE rabbis, called the "earlier scribes and sages" by Horsley (1996:181-184) can be seen as a "revitalization of village communities". After the temple was destroyed, the Pharisaic scribes and sages reorganized themselves in places such as Jamnia (in Judea), Galilee and Syria. There they tried to duplicate the old value systems of the temple in the households of the villages, especially regulations concerning hierarchy in society and the purity ideology of the temple. A similar activity of revitalizing village communities was found among the Jesus groups. The value system they implemented was based on Jesus' alternative understanding of the Torah. The difference in value systems and interests led to conflict between Pharisaic scribes and scribes among the followers of Jesus (see Dreyer 2001a).
} 
Pharisaic rabbinate, Matthew's community would have survived only with difficulty on the border between Galilee and Syria after the Bar-Kochba revolt.

\section{Works consulted}

Arnal, W E 2001. Jesus and the village scribes: Galilean conflicts and the setting of $Q$. Minneapolis: Fortress.

Bacon, B W [1930] 1980. Die "Fünf Bücher" des Matthäus gegen die Juden, übersetzt von W Wissmann, in Lange, J (Hrsg), Das Mattäus-Evangelium, 41-51. Darmstadt: Wissenschaftliche Buchgesellschaft.

Barth, G 1961 Das Gesetzesverständnis des Evangelisten Matthäus, in Bornkamm, G, Barth, G \& Held, H-J, Enderwartung und Kirche im Matthäusevangelium, 54154. 2.Auflage. Neukirchen: Neukirchener Verlag. (English translation: 1963, Matthew's understanding of the law, in Bornkamm, G, Barth, G \& Held, H-J, Tradition and interpretation in Matthew, 58-164. London: SCM.)

Bauckham, R [1985] 1995. The Son of Man: "A man in my position" or "someone"?, in Evans, C A \& Porter, S E (eds), The historical Jesus, 23-33. Sheffield: Academic Press. (A Sheffield Reader.)

Blair, E P 1967. Jesus and the salvation in the Gospel of Matthew. McCQ 20, 301-308.

Bornkamm, G 1961. Überlieferung and Auslegung im Mätthäusevangelium, in Bornkamm, G, Barth, G \& Held, H-J, Enderwartung und Kirche im Matthäusevangelium, 13-47. 2.Auflage. Neukirchen: Neukirchener Verlag.

Bultmann, R 1952. Theology of the New Testament, volume one, tr by K Grobel. London: SCM.

Bultmann, R 1965. History of the Synoptic tradition, tr by J Marsh. Revised edition. Peabody, MA: Hendrickson.

Carter, W 2000. Matthew and the margins: A socio-political and religious reading. Sheffield: Sheffield Academic Press. (JSNT Supplement Series 204.)

Casey, M 1976. The Son of Man problem. ZNW 67, 147-154.

Cohen, J D 1992. The place of the rabbi in Jewish society of the second century, in Levine, L I (ed), The Galilee in late antiquity, 157-173. New York, NY: Jewish Theological Seminary. 
Collins, A Y 1996. The origin of the designation of Jesus as "Son of Man", in Cosmology and eschatology in Jewish and Christian apocalypticism, 139-158. Leiden: Brill. (Supplements to the Journal for the Study of Judaism 50.)

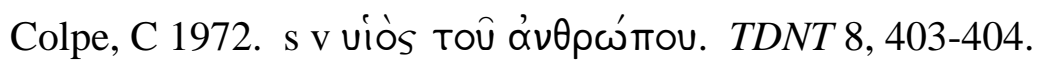

Crossan, J D (ed) 1986. Sayings Parallels: A wordbook for the Jesus tradition. Philadelphia, PA: Fortress. (Foundations and Facets.)

Davies, W D [1963] 1966. The setting of the sermon on the mount. Cambridge: Cambridge University Press.

Davies, W D \& Allison D C 1988. A critical and exegetical commentary on the Gospel according to Saint Matthew, Vol 1: Introduction and commentary on Matthew IVII. Latest impression. Edinburgh: $\mathrm{T} \& \mathrm{~T}$ Clark. (The International Critical Commentary on the Holy Scriptures of the Old and the New Testaments.)

Dodd, C H [1936] 1956, p. 16, “The Primitive Preaching," in The Apostolic Preaching and its Developments: Three Lectures with an Appendix on Eschatology and History, 7-35. Eight Impression. London: Hodder \& Stoughton.

Dreyer, Y 2001a. The tradition history of the Sayings Gospel Q and the "Christology" of $\mathrm{Q}^{3}$. Neotestamentica 34(2), 273-285.

Dreyer, Y 2001b. Gospel tradition and scribal activity. NGTT (Dutch Reformed Theological Journal) 42(3\&4), 315-327.

Duling, D C 1995a. The Matthean brotherhood and marginal scribal leadership, in Esler, (ed), Modeling early Christianity: Social-scientific studies of the New Testament in its context, 159-182. London: Routledge.

Duling, D C 1995b. Matthew and marginality. HTS 51(1),1-30.

Filson, F V 1960. The Gospel according to St Matthew. $2^{\text {nd }}$ edition. London: Black.

Garland, D E 1993. Reading Matthew: A literary and theological commentary on the irst Gospel. New York: Crossroad. (Reading the New Testament Series.)

Hare, D R A 1967. The theme of Jewish persecution of Christians in the Gospel according to St Matthew. Cambridge: Cambridge University Press. 
Hare, D R A 1993. Matthew. Louisville: John Knox Press. (Interpretation: A Bible Commentary for Teaching and Preaching).

Held, H-J 1961. Matthäus als Interpret der Wundergeschichten, in Bornkamm, G, Barth, G \& Held, H-J, Enderwartung und Kirche im Matthäusevangelium, 155-287. 2.Auflage. Neukirchen: Neukirchener Verlag.

Hengel, M 1995. "Sit at my right hand!", in Studies in early Christology, 119-226. Edinburgh: T \& T Clark.

Horsley, R A 1987. Jesus and the spiral of violence: Popular Jewish resistance in Roman Palestine. San Francisco: Harper \& Row.

Horsley, R A 1991. Q and Jesus: Assumptions, approaches and analyses. Semeia 55, 175-209.

Horsley, R A 1996. Archeology, history, and society in Galilee: The social context of Jesus and the rabbis. Valley Forge, PA: Trinity Press International.

Hummel, R 1966. Die Auseinandersetzung zwischen Kirche und Judentum im Matthäusevangelium. Munchen: Kaiser.

Jeremias, J [1938] 1985. s v “The power of the keys." TDNT. Abridged in One Volume, by G W Bromiley. Grand Rapids, MI: Eerdmans.

Käsemann, E 1954-55. Sätze heiligen Rechtes im Neuen Testament. NTS 1, 248-260.

Käsemann, E 1960. Die Anfänge christlicher Theologie. ZThK 57, 162-185.

Käsemann, E [1960] 1969. The beginnings of Christian theology, in New Testament questions of today, tr by W J Montague, 82-107. London: SCM Press. (The New Testament Library.)

Kloppenborg, J S 2000. Excavating Q: The history and setting of the Sayings Gospel. Minneapolis, MN: Fortress.

Klostermann, E 1938. Das Mattäusevangelium. 3.Auflage. Tübingen: Mohr.

Künzel, G 1978. Studien zum Gemeindeverständnis des Matthäusevangeliums. Stuttgart: Calwer.

Levine, L I 1992. The sages and the synagogue in late antiquity, in Levine, L E (ed), The Gailee in late antiquity, 201-222. New York, NY: Jewish Theological Seminary.

Luz, U [1985] 1989. Matthew 1-7: A commentary. Minneapolis: Fortress.

Luz, U [1989] 2001. Matthew 8-20: A commentary. Minneapolis: Fortress. 
Meier, J P 1976. Law and history in Matthew's gospel: A redactional study of Mt. 5:1748. Rome: Biblical Institute Press. (Ana.Bib. 71.)

Meier, J P 1997. The circle of the Twelve: Did it exist during Jesus' public ministry? JBL 116(4), 635-672.

Metzger, B 1971. A textual commentary on the Greek New Testament. Stuttgart: UBS.

Miller, R J (ed.) [1992] 1994. The complete gospels: Annotated Scholars Version. Revised and expanded edition. Sonoma, CA: Polebridge.

Mohrlang, R 1984. Matthew and Paul: A comparison of ethical perspectives. Camridge: Cambridge University Press. (SNTS Monograph Series 48.)

Murphy, F J 1994. Apocalypses and apocalypticism: The state of the question. Currents in Research: Biblical Studies 2, 147-180.

Neusner, J 1991. An introduction to Judaism: A textbook and reader. Louisville, KT: Westminster.

Orton, D E 1989. The understanding scribe: Matthew and the apocalyptic ideal. Shefield: Sheffield Academic Press. (JSNT Sup 25.)

Overman, J A 1990. Matthew's gospel and formative Judaism: The social world of the Matthean community. Minneapolis, MN: Fortress.

Riches, J 1997. Matthew. Sheffield: Sheffield Academic Press. (New Testament Guides.)

Saldarini, A J 1991. The Gospel of Matthew and Jewish-Christian conflict, in Balch, D L (ed), Social history of the Matthean community: Cross-disciplinary approaches, 38-61. Minneapolis: Fortress.

Saldarini, A J 1994. Matthew's Christian-Jewish community. Chicago: The University of Chicago Press. (Chicago Studies in the History of Judaism.)

Schams, C 1998. Jewish scribes in the Second-Temple period. Sheffield: Sheffield Academic Press. (JSOT Supplement Series 291.)

Schlatter, A [1933] 1963. Der Evangelist des Matthäus. Seine Sprache, seine Ziel, seine Selbbeständigkeit: Eine Kommentar zum ersten Evangelium. 6.Auflage. Stuttgart: Calwer.

Schmithals, W 1973. Die Apokalyptik: Einfürung und Deutung. Göttingen: Vandenhoeck. (Sammlung Vandenhoeck.) 
Schmithals, W 1975. Jesus und die Apokalyptik, in Strecker, G (Hrsg), Jesus Christus in Historie und Theologie: Festschrift für Hans Conzelmann, 59-85. Tübingen: Mohr.

Schmithals, W 1986. Das Evangelium nach Markus: Kapitel 1,1-9,1. 2.Auflage. Güterloh: Gütersloher Verlagshaus Gerd Mohn. (Ökumenischer Taschenbuch-Komenar zum Neuen Testament 2/1.)

Schmithals, W 1994. Theologiegeschichte des Urchristentums: Eine problemgeschichtliche Darstellung. Stuttgart Kohlhammer..

Schweizer, E 1974. Matthäus und seine Gemeinde. Stuttgart: KBW.

Senior, D 2001. Directions in Matthean studies, in Aune, D E (ed), The Gospel of Matthew in current study: Studies in memory of William G Thompson, 5-21. Grand Rapids, MI: Eerdmans.

Sim, D C 1996. Apocalyptic eschatology in the Gospel of Matthew. Cambridge: Cambridge University Press. (SNTSMS 88.)

Sim, D C 1998. The Gospel of Matthew and Christian Judaism: The history and social setting of the Matthean community. Edinburgh: T\& T Clark. (Studies of the New Testament and its World.)

Stanton, G 1992. A Gospel for a new people: Studies in Matthew. Edinburgh: T \& T Clark.

Theissen, G [1999] 1999. A theory of primitive Christian religion, tr by J Bowden. London: SCM.

Van Aarde, A G 1994. God-with-us: The dominant perspective in Matthew's story, and other essays. Pretoria: Gutenberg. (HTS Suppl, University of Pretoria.)

Van Aarde, A G 1999. The historicity of the circle of the twelve: All roads lead to Jerusalem. HTS 55(4), 795-826.

Vermes, G 1967. The use of bar noshah / nosh in Jewish Aramaic, in Black, M (ed), An Aramaic approach to the gospels and Acts (Appendix E). Oxford: Clarendon. 